\title{
Partial neutralization of rain by seaspray: The case of Recôncavo, Bahia-Brazil
}

\author{
Vânia P. Campos*, Angela Cristina A. Costa, Tania M. Tavares \\ LAQUAM - Laboratório de Química Analítica Ambiental, Departamento de Química Analítica, Instituto de Química da Universidade Federal da Bahia, \\ Campus Universitário de Ondina, s/n CEP 40170-290, Salvador, BA, Brazil
}

Received 8 June 2005; received in revised form 10 May 2006; accepted 18 May 2006

Available online 18 September 2006

\begin{abstract}
In the Recôncavo of Bahia (located between $12^{\circ} 33^{\prime}$ and $13^{\circ} 10^{\prime} \mathrm{S}$ and $38^{\circ} 00^{\prime}$ and $39^{\circ} 00^{\prime} \mathrm{W}$ ), there are significant discharges of $\mathrm{SO}_{2}$ and $\mathrm{NO}_{x}$ due to local, industrial and urban activities. The incoming air masses from the Atlantic Ocean are enriched with seaspray, which neutralizes part of the rain acidity. The extent of seaspray neutralization of rain acidity was quantified in four sites of the region, each with different loads of seaspray. Rain samples were obtained daily at the same time, integrating the precipitation of the previous $24 \mathrm{~h}$, using wet-only collectors and analyzed for $\mathrm{pH}$ by potentiometry and for sodium by flame photometry. The amount of rain acidity in Recôncavo neutralized by seaspray ranged from $<1 \%$ up to $88 \%$ and depended on the site. On average, neutralization ranged from $5 \%$ to $18 \%$.
\end{abstract}

(C) 2006 Elsevier Ltd. All rights reserved.

Keywords: Rain neutralization; Seaspray; Wet deposition; Marine aerosol

\section{Introduction}

The Recôncavo of Bahia comprises the Todos os Santos Bay $\left(1052 \mathrm{~km}^{2}\right.$ ), its islands (more than 30 ) and surrounding areas. In this region, the largest petrochemical complex in the Southern Hemisphere is located with about 50 plants and an additional industrial park, comprised of more than 250 industries. To the southeast is the city of Salvador, the capital of Bahia state, currently with a population of 2.5 million.

Previous studies in the Recôncavo of Bahia showed that sulfate was the main anion from anthropogenic origin in rain (Campos, 1995; Tavares et al., 1993; Campos et al., 1998). Wet-only deposition samples, collected in the same sites of the present study, demonstrated average excess sulfate values (subtracted from the sulfate coming from seaspray) within the range of $11-40 \mu \mathrm{mol} \mathrm{L}^{-1}$, with a volume-weighted mean of $22.6 \mu \mathrm{mol} \mathrm{L}^{-1}$. There was a corresponding concentration of $8.63 \mu \mathrm{mol} \mathrm{L}^{-1}$ for nitrate. Examination of the ammonium ion concentration in rain

\footnotetext{
*Corresponding author. Tel.: + $557132374024 / 32374133$; fax: +557132374024 .

E-mail address: vaniaroc@ufba.br (V.P. Campos).
}

collected in four stations from the Recôncavo (Campos, 1995) revealed that, at the coast of Salvador, there was not enough $\mathrm{NH}_{4}^{+}$in rain to neutralize the excess of sulfate. In contrast to these findings in Recôncavo, Lee et al. (2000) reported a significantly low level of $\mathrm{H}^{+}$concentration in South Korea rain, presumably due to neutralization by ammonia and calcium compounds. The volumeweighted mean concentration for calcium compounds measured in rain from Recôncavo was low (about $\left.6 \mu \mathrm{mol} \mathrm{L}^{-1}\right)$, considering values from other sites of the world, including maritime (Warneck, 1988). Similarly, bicarbonate $\left(0.90 \mu \mathrm{mol} \mathrm{HCO}_{3}^{-} \mathrm{L}^{-1}\right)$ and carbonate $\left(10^{-5} \mu \mathrm{mol} \mathrm{CO}_{3}^{2-} \mathrm{L}^{-1}\right)$ were also low, both calculated using the expression for the dissolution equilibrium of $\mathrm{CO}_{2} /$ water at $25^{\circ}$ as a function of $\mathrm{H}^{+}$concentration measured as $\mathrm{pH}$. (Granat, 1972). In Recôncavo, it is believed that seaspray neutralization was responsible for the absence of acid rain and for up to $27 \%$ of rain events considered as alkaline, with average $\mathrm{pH}$ values above 5.6 which corresponds to the equilibrium of atmospheric $\mathrm{CO}_{2}$ with precipitation. The overall volume weighted mean $\mathrm{pH}$ value of rain in the Recôncavo was 5.0 calculated from measurements in different sites (Campos, 1995). This value was identified as the most frequent lower limit within the range of 
"natural $\mathrm{pH}$ " of precipitation in maritime and continental areas of different parts of the world (Galloway et al., 1982).

The atmospheric aerosol of the Recôncavo is abundant in seaspray particles (Tavares et al, 1993). These particles, basically composed of seawater $(\mathrm{NaCl}$ in carbonate/borate buffer), are able to neutralize rain acidity by gas to particle interaction (Bruynseels et al., 1985), where acid rain precursors and their oxidation products in the atmosphere are scavenged by Brownian diffusion and/or diffusionforesis, or by their incorporation into rain due to impaction and interception followed by reaction in aqueous phase.

Several researchers reported on the acid rain neutralization by different compounds present in the atmosphere (Kramer, 1978; Charlson and Rodhe, 1982; Galloway et al., 1983; Munger and Eisenreich, 1983; Loye-Pilot et al., 1986; Ezcurra et al., 1988; Possanzini et al., 1988; Ahmed et al., 1990; Gillett et al., 1990; Al-Momani et al., 1995; Sharma and McBean, 1995; Sanusi et al., 1996; Saxena et al., 1996; Zhou and Tazaki, 1996; Satsangi et al., 1998; Avila and Peñuelas, 1999; Herut et al., 2000; Tuncer et al., 2001; Flues et al., 2002; Glavas and Moschonas, 2002; Terada et al., 2002; Al Momani, 2003; Kulshrestha et al., 1996, 2003). Most of these studies showed that rain, originally acid, was neutralized by mineral grains, mainly carbonates, and/or dissolved gases $\left(\mathrm{NH}_{3}\right)$. However, few authors have reported rain neutralization by seaspray.

Chameides and Stelson (1992) investigated the aqueous phase chemistry of deliquescent sea salt aerosols with a steady-state box model. Due to the alkalinity of sea salt, their calculations indicated that these aerosols were strongly buffered and as a result their $\mathrm{pH}$ remained close to 8 until the amount of acid added to the aerosol solution exceeded the alkalinity. Galloway et al. (1982) and Jickells et al. (1982) observed that measurements in different parts of the world showed that the amount of acid components in precipitation was controlled by the trajectory of air masses and that there was an interaction between seaspray and those components.

This paper reports our attempts to quantify seaspray contribution to the neutralization of rain acidity in a coastal tropical atmosphere receiving trade winds from the South Atlantic, Recôncavo of Bahia taken as a case study.

\section{Experimental section}

\subsection{Sampling}

Four sampling stations were established (Fig. 1): Ondina in Salvador (I), at $500 \mathrm{~m}$ from the ocean coastline at $50 \mathrm{~m}$ high, considered as a reference in this work; this site receives Atlantic air masses at all times, with little urban influence; CIBEB (Industrial Beverage Company of Bahia), on top of a $30 \mathrm{~m}$ high hill, at $2 \mathrm{~km}$ downwind from the Petrochemical Complex of Camaçari (III), at equivalent height of its main chimneys; CEPLAC (Research Center of Cocoa Plantation-Experimental Station), about 12-40 km downwind from the main industrial centers of the region (IV, II and III), at $5 \mathrm{~m}$ high in relation to sea level; Pedra do Cavalo, an artificial reservoir of Paraguaçu River, about $70 \mathrm{~km}$ downwind from Salvador and industrial sources (I-IV), at $110 \mathrm{~m}$ above sea level.

In the four sites, wet-only deposition collectors were used. Collectors were designed and built by the Nuclear Research Center of Jülich, equipped with a lid operated

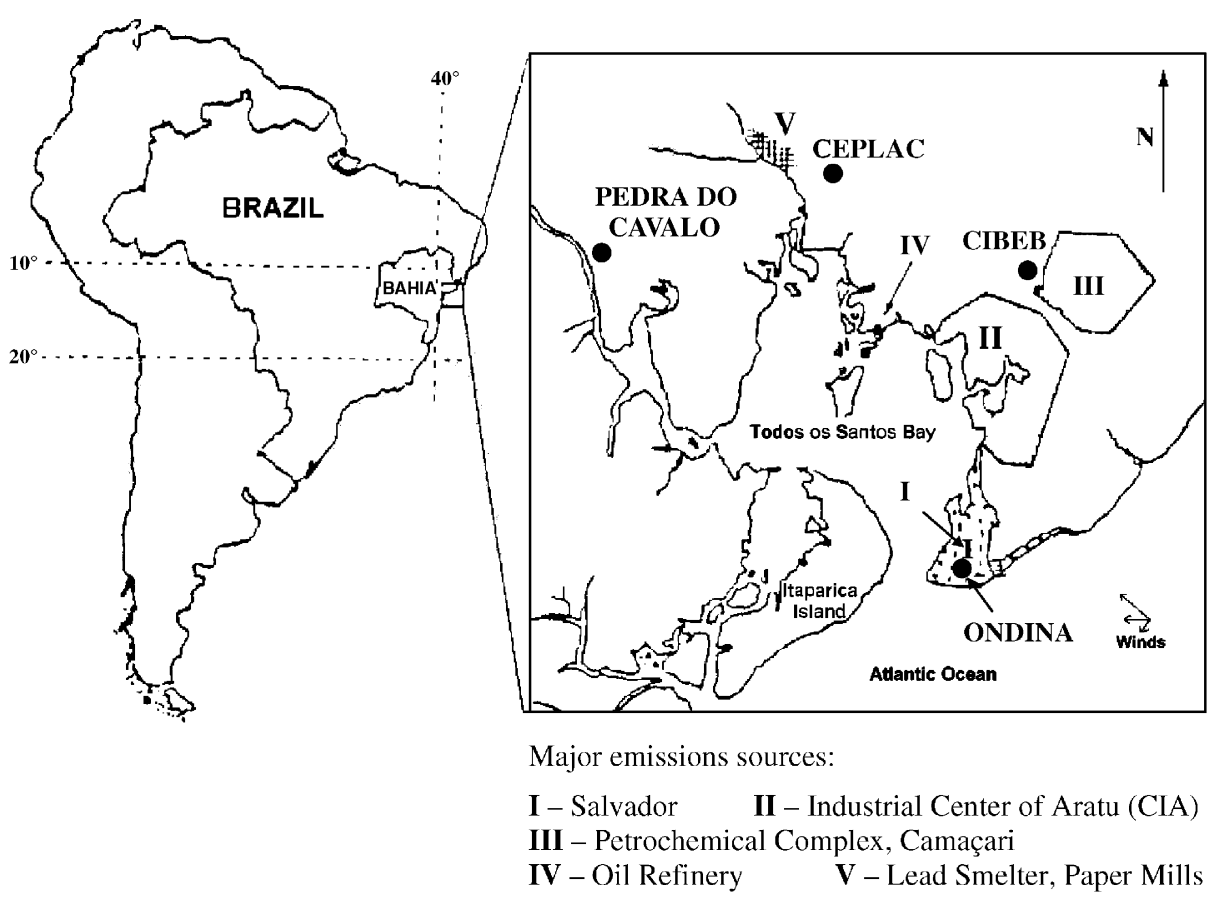

Fig. 1. Map of Recôncavo in Bahia area showing the rain sampling stations (Ondina, CIBEB, CEPLAC and Pedra do Cavalo) and the major five emission sources of the region $(\mathrm{I}-\mathrm{V})$. 
with a moist sensor which makes it open when the first drops of rain occur and close upon dryness. This type of rain collector minimizes the positive bias introduced by the dry deposition components of open collectors. When the lid is opened, rain is collected on a funnel with a $598-\mathrm{cm}^{2}$ area as inlet and stored in a polyethylene bottle of $6 \mathrm{~L}$. Both are enclosed in opaque PVC housing to protect against animals, deposition of other materials and light, thus avoiding possible undesirable chemical and some photo-biochemical reactions during collection.

The collected rain samples were taken daily at the same time, thus representing the precipitation of a $24 \mathrm{~h}$ interval during a 1.5-year period, from August 1996 to December 1997, totaling 182 samples. The total volume of each sample was determined by weighing the total amount of collected rain (collecting bottle previously weighted) and assuming the density of water is equal to $1 \mathrm{~g} \mathrm{~cm}^{-3}$ at all times. The amount of precipitation in millimeters was determined by dividing the volume of collected rain by the funnel area. Three parts of each sample were transferred to $20 \mathrm{~mL}$ polypropylene flasks and stored in a refrigerator $\left(4^{\circ} \mathrm{C}\right)$ until analysis, which took place in 1 week.

\subsection{Analyses}

The $\mathrm{pH}$ of rain samples was measured by potentiometry, using a combined glass microelectrode calibrated with Fischer certificate buffer solutions of $\mathrm{pH} 4.00 \pm 0.01$ and $7.00 \pm 0.01$, at $25^{\circ} \mathrm{C}$. To each rain sample $(1500 \mu \mathrm{L}), 5 \mu \mathrm{L}$ of saturated $\mathrm{KCl}$ solution were added, in order to improve the ionic strength and consequently the reproducibility of the measurement conditions. The measurements were carried out in non-stirred solutions until a stable reading could be reached (approximately $1 \mathrm{~min}$ ).

Sodium concentration in rain samples was determined by flame photometry (detection limit of $6 \times 10^{-2} \mu \mathrm{g} \mathrm{Na} \mathrm{mL}^{-1}$ ), using the stock standard solution prepared from $\mathrm{NaCl}$, previously dried at $115^{\circ} \mathrm{C}$. As no other known sources of sodium exist in the sampling sites, sodium was used as a marine tracer for the seaspray quantification, taking into account the seawater alkalinity, according to Skirrow (1975), using the equations shown in the next section. The concentrations of the involved species originated from reported values for uncontaminated seawater with salinity of 34\%, as in the local situation (Tavares et al., 1993). Conductivity measurements and analyses of $\mathrm{Cl}^{-}, \mathrm{NO}_{3}^{-}$, $\mathrm{SO}_{4}^{2-}, \mathrm{Ca}^{2+}, \mathrm{Mg}^{2+}, \mathrm{NH}_{4}^{+}$and $\mathrm{K}^{+}$were carried out in rain samples and are not shown in this paper. However, it is important to note that these measurements were used together with sodium concentration data to control the quality of rain analysis by ion equivalent mass balance (the sum of cation equivalents vs. the sum of anion equivalents) and comparisons between calculated and measured conductivities. Accuracy was additionally checked by artificial rain samples as controls.

\section{Theory and calculation}

The amphiprotic properties of water bring about solvolytic reactions of weak acid anions, for example,

$\mathrm{HCO}_{3}{ }^{-}+\mathrm{H}_{2} \mathrm{O} \Leftrightarrow \mathrm{H}_{2} \mathrm{CO}_{3}+\mathrm{OH}^{-}$.

Similar reactions occur with carbonate and borate ions. As a result of this equilibrium, the $\mathrm{pH}$ of seawater is alkaline. The alkalinity of a seawater sample is expressed by the amount of hydrogen ion that is needed to convert all the weak acid anions to their unionized acids and it is given by expression (1), which regards the electroneutrality of the solution (Skirrow, 1975):

$$
\begin{aligned}
{[\mathrm{Alk}]_{\mathrm{sw}}=} & C_{\mathrm{HCO}_{3(\mathrm{~T})}^{-}}+2 C_{\mathrm{CO}_{3(\mathrm{~T})}^{2-}}+C_{\mathrm{B}(\mathrm{OH})_{4}^{-}} \\
& +\left(C_{\mathrm{OH}^{-}}-C_{\mathrm{H}^{+}}\right)+\mathrm{C}_{\mathrm{SA}},
\end{aligned}
$$

The $C$ term refers to total equilibrium concentrations at a certain temperature $T$, and $C_{\mathrm{SA}}$, surplus alkalinity, refers to the sum concentrations of all weak acid anions other than carbonic and boric acids. According to Skirrow (1975), for uncontaminated seawater of $\mathrm{pH} 8.3$ at $10^{\circ} \mathrm{C}$, $C_{\mathrm{HCO}_{3}^{-}}, C_{\mathrm{CO}_{3}^{2-}}$ and $C_{\mathrm{B}(\mathrm{OH})_{4}^{-}}$are about $2 \times 10^{-3}, 2 \times 10^{-4}$ and $1 \times 10^{-4} \mathrm{~mol} \mathrm{~L}^{-1}$, respectively, whereas $\left(C_{\mathrm{OH}^{-}}-C_{\mathrm{H}^{+}}\right)$ is only $2 \times 10^{-6} \mathrm{~mol} \mathrm{~L}^{-1}$ and can be disregarded. For most ocean waters, surplus alkalinity is small enough to be ignored; therefore the expression of seawater alkalinity reduces to

$$
[\mathrm{Alk}]_{\mathrm{sw}}=C_{\mathrm{HCO}_{3(\mathrm{~T})}^{-}}+2 C_{\mathrm{CO}_{3(\mathbf{T})}^{2-}}+C_{\mathrm{B}(\mathrm{OH})_{4}^{-}}
$$

Table 1

Average alkalinity from seaspray, average total acidity and neutralization of the precipitation in Recôncavo of Bahia, Brazil

\begin{tabular}{lllll}
\hline $\begin{array}{l}\text { Sampling station (sampling } \\
\text { period) }\end{array}$ & $\begin{array}{l}\text { Ondina (May-December } \\
1997)\end{array}$ & $\begin{array}{l}\text { CIBEB (August-November } \\
1996)\end{array}$ & $\begin{array}{l}\text { CEPLAC } \\
\text { (August-December 1996) }\end{array}$ & $\begin{array}{l}\text { Pedra do Cavalo (August } \\
1996-O c t o b e r ~ 1997)\end{array}$ \\
\hline $\begin{array}{l}\text { Distance from Atlantic } \\
\text { coast line }\end{array}$ & $500 \mathrm{~m}$ & $22 \mathrm{~km}$ & $55 \mathrm{~km}$ & $120 \mathrm{~km}$ \\
$\begin{array}{l}\text { Number of samples } \\
\text { Mean }[\mathrm{Alk}]_{\mathrm{ss}}\left(\mu \mathrm{mol} \mathrm{L}^{-1}\right)\end{array}$ & 34 & 37 & 56 & 55 \\
Mean $\left[\mathrm{H}^{+}\right]_{\mathbf{T}}\left(\mu \mathrm{mol} \mathrm{L}^{-1}\right)$ & $6.4 \pm 3.6$ & $0.70 \pm 0.82$ & $0.53 \pm 0.46$ & $0.38 \pm 0.43$ \\
$\begin{array}{l}\text { Neutralization by seaspray }(\%) \\
\quad \begin{array}{l}\text { Average } \\
\text { Range }\end{array}\end{array}$ & $19 \pm 17$ & $19 \pm 14$ & $7.1 \pm 7.0$ \\
\hline
\end{tabular}


The above equilibrium provides seawater with the particularly important property of buffering its own $\mathrm{pH}$. This buffering strongly accounts for the control of oceanic $\mathrm{pH}$ when considering time scale in hundreds or thousands of years. Seaspray was originally formed by seawater components, thus keeping its buffering capacity within a certain range. Therefore, it is likely that seaspray particles can neutralize part of the acids in wet deposition.
NOAA HYSPLIT MODEL

Backward trajectory ending at 10 UTC 20 Sep 97 CDC1 Meteorological Data

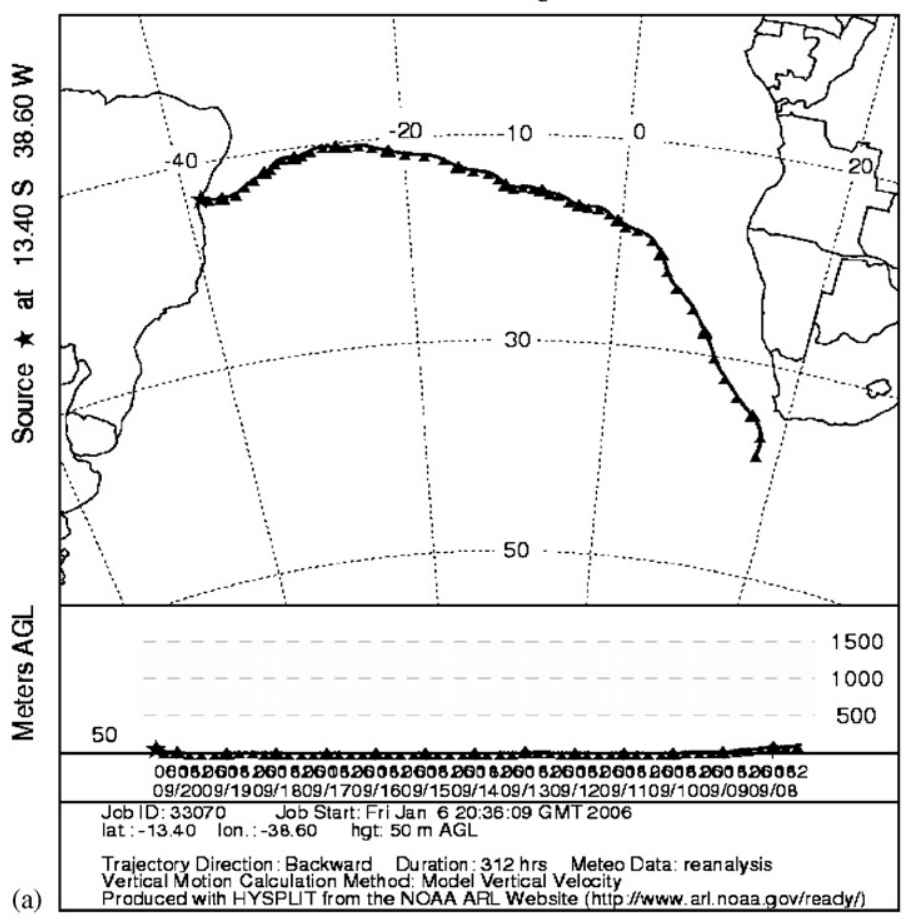

NOAA HYSPLIT MODEL

Backward trajectory ending at 10 UTC 03 Dec 98 CDC1 Meteorological Data

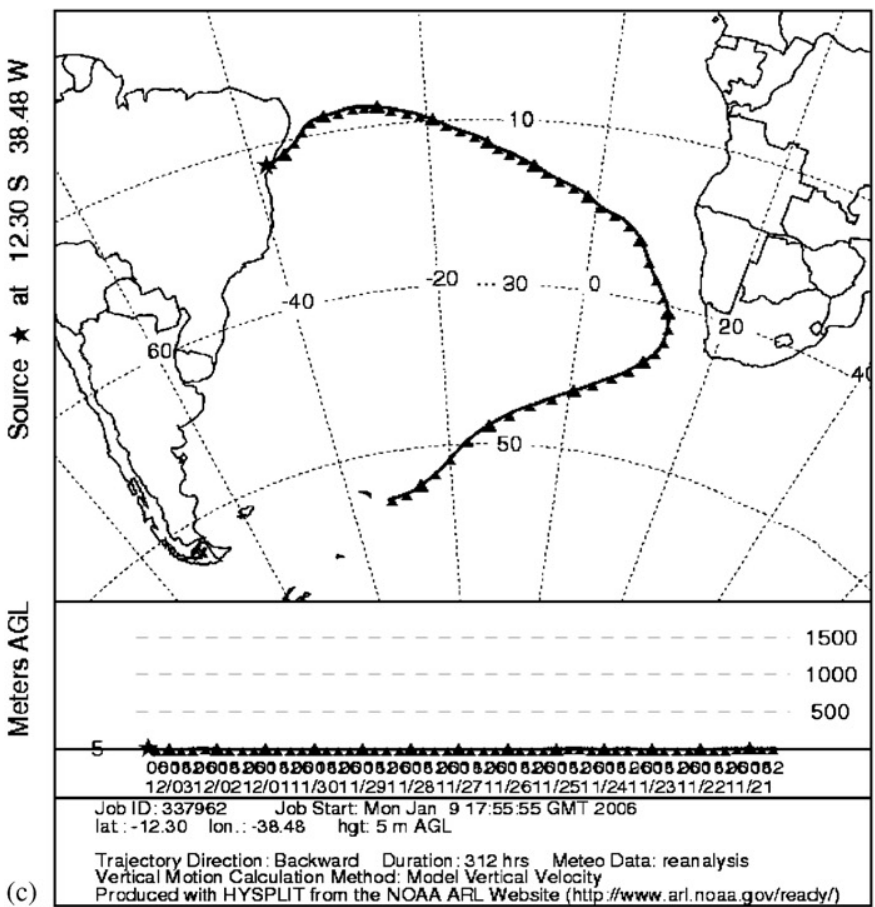

NOAA HYSPLIT MODEL

Backward trajectory ending at 10 UTC 27 Oct 96 CDC1 Meteorological Data

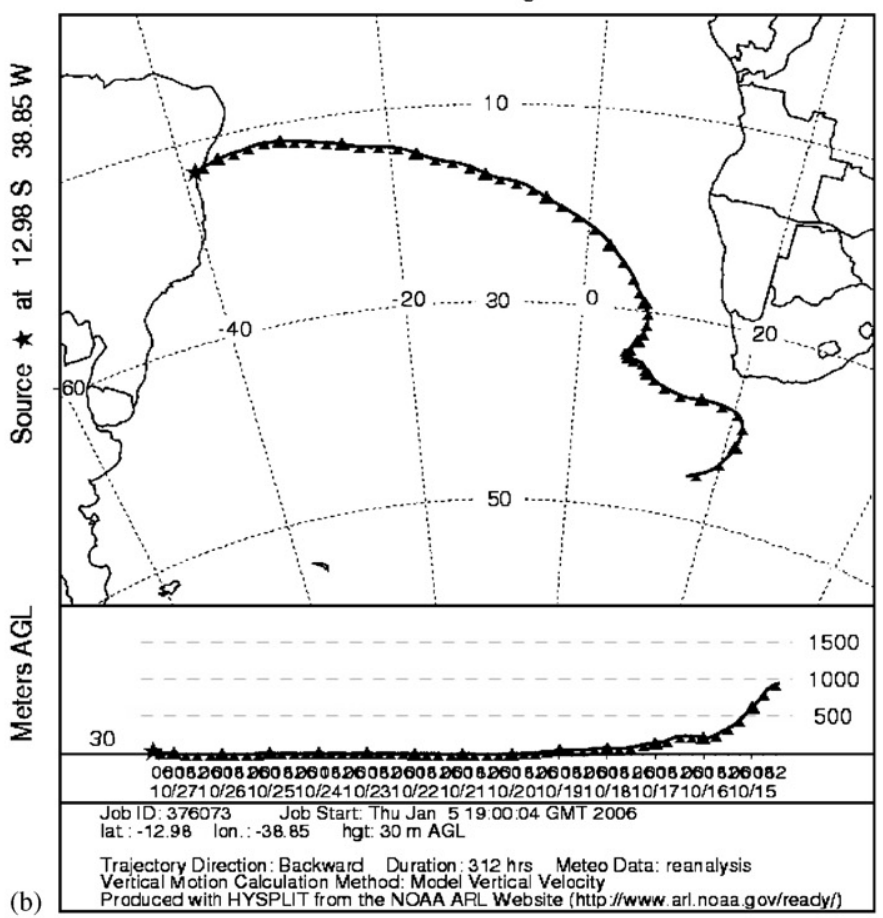

NOAA HYSPLIT MODEI

Backward trajectory ending at 10 UTC 25 Feb 97 CDC1 Meteorological Data

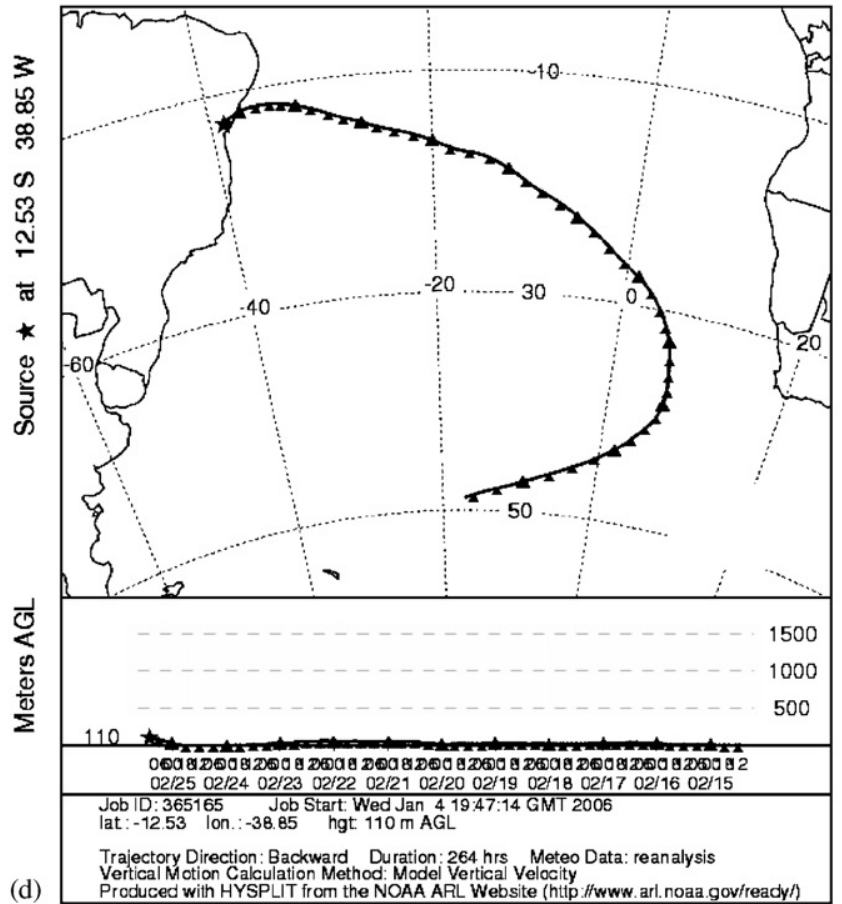

Fig. 2. Typical backward trajectories for Ondina (a), CIBEB (b), CEPLAC (c) and Pedra do Cavalo (d) in the Recôncavo of Bahia, Brazil. 


\subsection{Quantification of the neutralization}

A way to quantify how much rain acidity was neutralized by seaspray was proposed by Galloway et al. (1983), considering that the $\mathrm{Na}^{+}$concentration in precipitation was of marine origin. As there are no sources of this ion in the atmosphere of the Recôncavo, the following expression was used, as proposed by those authors to calculate the alkalinity of seaspray $\left(\mathrm{Alk}_{\mathrm{ss}}\right)$ :

$[\mathrm{Alk}]_{\mathrm{ss}}=0.00484\left[\mathrm{Na}^{+}\right]_{\mathrm{ppt}}$.

The total acidity of precipitation, $\left[\mathrm{H}^{+}\right]_{\mathbf{T}}$, was obtained as the sum of measured hydrogen ion concentration in rain $\left[\mathrm{H}^{+}\right]_{\text {meas. }}$, and its fraction of alkalinity originating from sea salt $\left[\mathrm{Alk}_{\mathrm{ss}}\right]$ :

$\left[\mathrm{H}^{+}\right]_{\mathrm{T}}=\left[\mathrm{H}^{+}\right]_{\text {meas. }}+[\mathrm{Alk}]_{\mathrm{ss}}$.

Seaspray alkalinity $[\mathrm{Alk}]_{\mathrm{ss}}$ was calculated considering seawater alkalinity $[\mathrm{Alk}]_{\mathrm{sw}}$ and sodium ion as a marine tracer (its concentration in precipitation, that is, in rain samples) $\left[\mathrm{Na}^{+}\right]_{\mathrm{ppt}}$, and in the seawater $\left[\mathrm{Na}^{+}\right]_{\mathrm{sw}}$ :

$[\mathrm{Alk}]_{\mathrm{ss}}=\left[\mathrm{Na}^{+}\right]_{\mathrm{ppt}}[\mathrm{Alk}]_{\mathrm{sw}} /\left[\mathrm{Na}^{+}\right]_{\mathrm{sw}}$.

Ondina

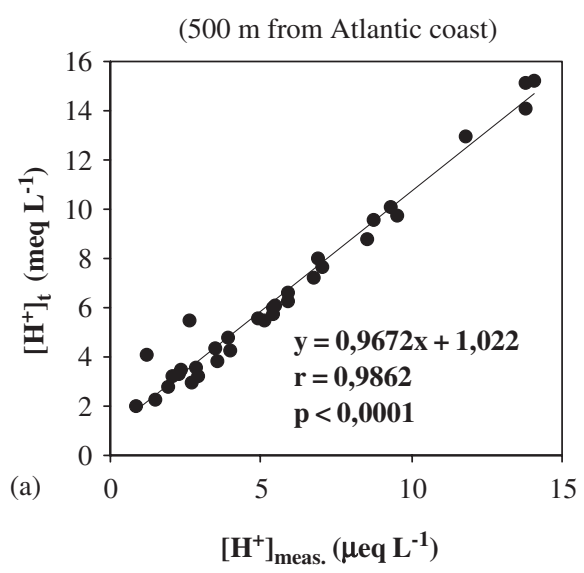

PEDRA DO CAVALO

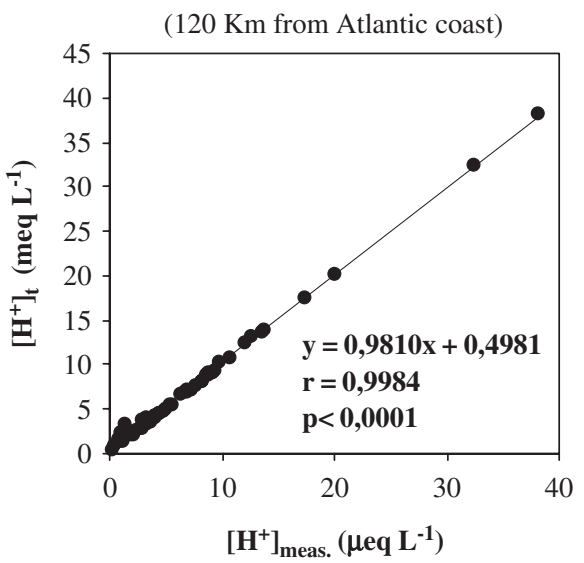

Galloway et al. (1983) considered $[\mathrm{Alk}]_{\mathrm{sw}}=2.30 \times$ $10^{-3} \mathrm{~mol} \mathrm{~L}^{-1}$ and $\left[\mathrm{Na}^{+}\right]_{\mathrm{sw}}=4.68 \times 10^{-1} \mathrm{~mol} \mathrm{~L}^{-1}$. So the ratio $[\mathrm{Alk}]_{\mathrm{sw}} /\left[\mathrm{Na}^{+}\right]_{\mathrm{sw}}$ was 0.00484 for Western Atlantic oceanic conditions, where sampling took place on a ship. However, considering coastal conditions of Recôncavo (temperature of $25^{\circ} \mathrm{C}$ and salinity of $34 \%$ ), and substituting the concentration values of these species with local seawater values, $[\mathrm{Alk}]_{\mathrm{sw}}=2.80 \times 10^{-3} \mathrm{~mol} \mathrm{~L}^{-1}$ and $\left.\left[\mathrm{Na}^{+}\right]_{\mathrm{sw}}=4.65 \times 10^{-1} \mathrm{~mol} \mathrm{~L}^{-1}\right)$, the ratio $[\mathrm{Alk}]_{\mathrm{sw}} /\left[\mathrm{Na}^{+}\right]_{\mathrm{sw}}$ changes to 0.00602 . These values have been calculated from tables compiled by Skirrow (1975) for concentrations of the major ions in seawater of various salinities. Then, expression (6) was used to calculate seaspray alkalinity in the stations of Recôncavo instead of expression (3) used by Galloway et al. (1983):

$[\mathrm{Alk}]_{\mathrm{ss}}=0.00602\left[\mathrm{Na}^{+}\right]_{\mathrm{ppt}}$.

Table 1 shows the average alkalinity of seaspray in rain samples from the four stations calculated by the above expression. The total mean acidity for these samples was calculated as

$\left[\mathrm{H}^{+}\right]_{\mathrm{T}}=\left[\mathrm{H}^{+}\right]_{\text {meas. }}+0.00602\left[\mathrm{Na}^{+}\right]_{\text {ppt }}$.

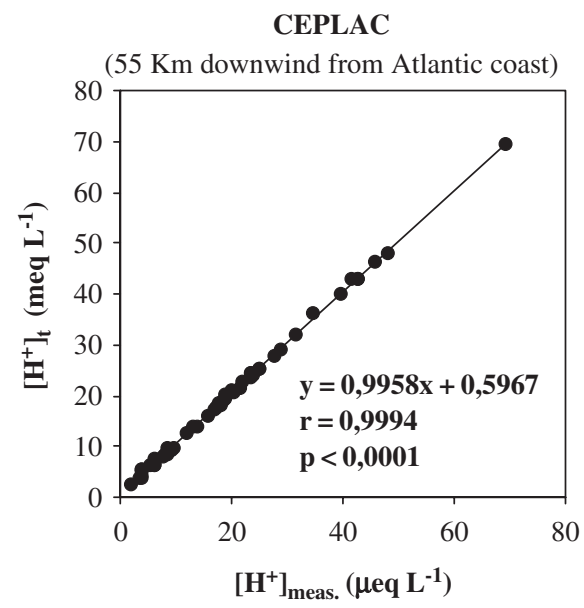

CIBEB

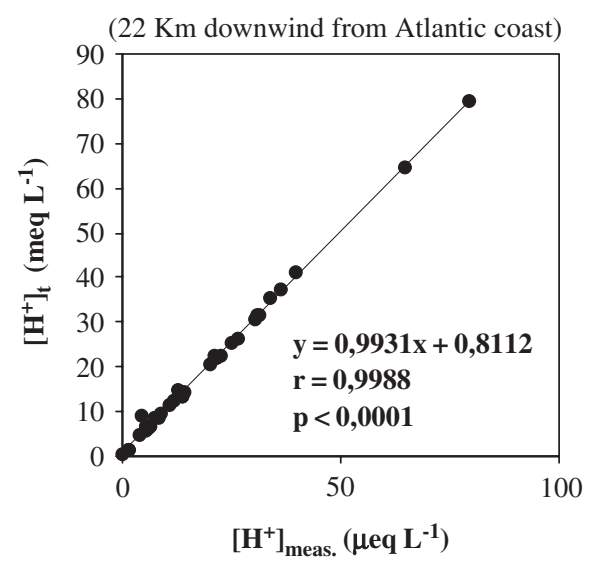

Fig. 3. Relationship between $\left[\mathrm{H}^{+}\right]_{\text {meas. }}$ and $\left[\mathrm{H}^{+}\right]_{\mathbf{T}}$ in the precipitation of Recôncavo area, considering the seaspray alkalinity. 


\section{Discussion}

Table 1 shows the percentage of neutralization by seaspray of precipitation acidity, regarding it as the difference between total and measured acidities in the samples. The high values of standard deviations of the average values reflected the large dispersion of the neutralization percentages. This is due to wind fluctuation during rainy periods, which controls the amount of transported seaspray to the sampling sites to be incorporated into wet deposition. The prevailing winds of the Recôncavo region come from the Atlantic Ocean, 32\% from the southeast, $24 \%$ from the east and $11 \%$ from the northeast. The rest of the time, there is either wind from other directions $(19 \%)$ or calmness $(14 \%)$.

Figs. 2(a)-(d) show typical backward trajectories for each station, calculated using the NOAA HYSPLIT MODEL. As there were many sampling days at each station, a minimum of seven backward trajectory graphs have been generated for each station in different periods. All generated figures indicate that air masses reaching these sites originate from the Atlantic Ocean, in a similar manner as those presented in Figs. 2(a-d).

\subsection{Evidence of participation of seaspray in rain neutralization}

Measured hydrogen ion concentration is the result of the total hydrogen ion concentration originally present less than the part of this concentration considered as neutralized by the seaspray based on sodium ion measurements in rain.

Fig. 3 presents a strong relationship between measured $\mathrm{H}^{+}$concentration $\left(\left[\mathrm{H}^{+}\right]_{\text {meas. }}\right)$ in the sampled rain at the four sites and total $\mathrm{H}^{+}$concentration $\left(\left[\mathrm{H}^{+}\right]_{\text {meas. }}+[\mathrm{Alk}]_{\mathrm{ss}}\right)$, showing that the assumption of seaspray neutralization of the rain fit well with the measurements. Fig. 4 shows how the seaspray influenced rain at each site: the higher the $[\mathrm{Alk}]_{\mathrm{ss}} \%$, the higher the $\mathrm{pH}$ of the rain.

The total acidity in rain of Recôncavo was calculated by Eq. (7) for each rain sample. If the ratio $\left[\mathrm{Na}^{+}\right]_{\mathrm{ppt}} /$ $\left[\mathrm{H}^{+}\right]_{\text {meas. }}$ is $\leqslant 18$, it is deduced that the neutralization of precipitation acidity by seaspray is $\leqslant 10 \%$. Similarly, when $\left[\mathrm{Na}^{+}\right]_{\text {ppt }} /\left[\mathrm{H}^{+}\right]_{\text {meas }} \geqslant 18$, the ratio $\left[\mathrm{Alk}_{\mathrm{ss}}\right] /\left[\mathrm{H}^{+}\right]_{\mathbf{T}}$ is $\geqslant 10 \%$. The value 18 is explained below. If both sides of Eq. (7) are divided by $\left[\mathrm{H}^{+}\right]_{\text {meas. }}$, the following equation is obtained:

$\left[\mathrm{H}^{+}\right]_{\mathrm{T}} /\left[\mathrm{H}^{+}\right]_{\text {meas. }}=1+0.00602\left[\mathrm{Na}^{+}\right]_{\mathrm{ppt}} /\left[\mathrm{H}^{+}\right]_{\text {meas }}$
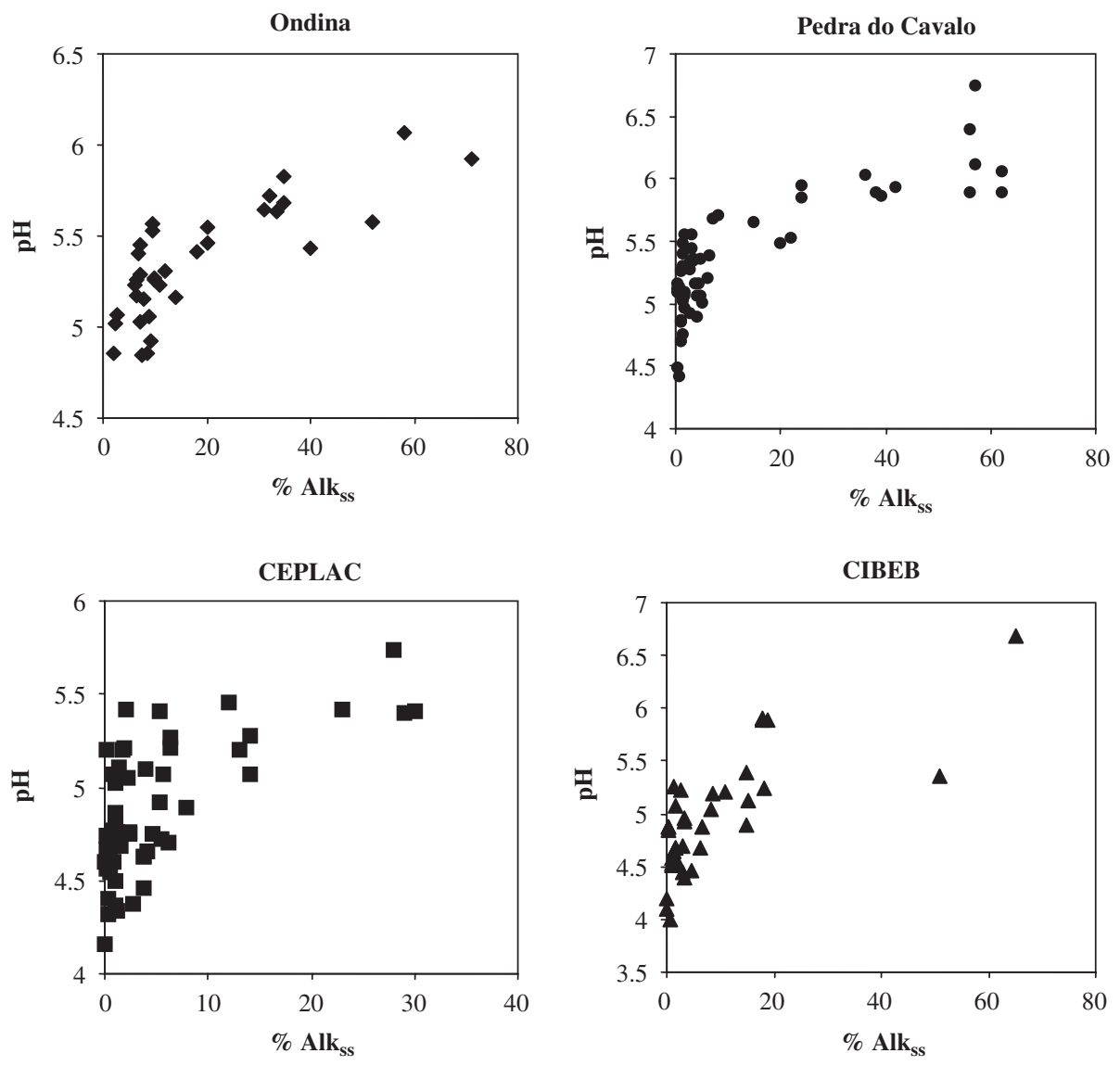

Fig. 4. Influence of the seaspray on the rain at the four sites of Recôncavo, Bahia, Brazil. 
However, if the alkalinity of seaspray $\left([\mathrm{Alk}]_{\mathrm{ss}}\right)$ is $\leqslant 10 \%$ of total rain acidity $\left[\mathrm{H}^{+}\right]_{\mathrm{T}}$, that is, if $0.00602\left[\mathrm{Na}^{+}\right]_{\mathrm{ppt}} \leqslant 0.1\left[\mathrm{H}^{+}\right]_{\mathrm{T}}$, the following expression is obtained by substitution in Eq. (7):

$\left[\mathrm{H}^{+}\right]_{\mathrm{T}}=\left[\mathrm{H}^{+}\right]_{\text {meas. }}+0.1\left[\mathrm{H}^{+}\right]_{\mathrm{T}}$.

Thus, rain acidity determined by $\mathrm{pH}$ measurement $\left(\left[\mathrm{H}^{+}\right]_{\text {meas }}\right)$ will correspond to a minimum of $90 \%$ of total acidity, that is, $0.9\left[\mathrm{H}^{+}\right]_{\mathbf{T}}<\left[\mathrm{H}^{+}\right]_{\text {meas. }}$. Therefore, it is deduced that $\left[\mathrm{H}^{+}\right]_{\mathbf{T}}<\left[\mathrm{H}^{+}\right]_{\text {meas. }} / 0.9$.

Substituting $\left[\mathrm{H}^{+}\right]_{\mathbf{T}}$ in Eq. (8) by $\left[\mathrm{H}^{+}\right]_{\text {meas. }} / 0.9$, it is found that

$\left[\mathrm{Na}^{+}\right]_{\mathrm{ppt}} /\left[\mathrm{H}^{+}\right]_{\text {meas. }} \leqslant 0.111 / 0.00601$, that is, $\left[\mathrm{Na}^{+}\right]_{\mathrm{ppt}} /$ $\left[\mathrm{H}^{+}\right]_{\text {meas. }} \leqslant 18$.

\subsection{Importance of seaspray as a neutralizing agent for rain acidity}

Fig. 5 shows the neutralization parameters cited above. It also shows the importance of seaspray as a neutralizing
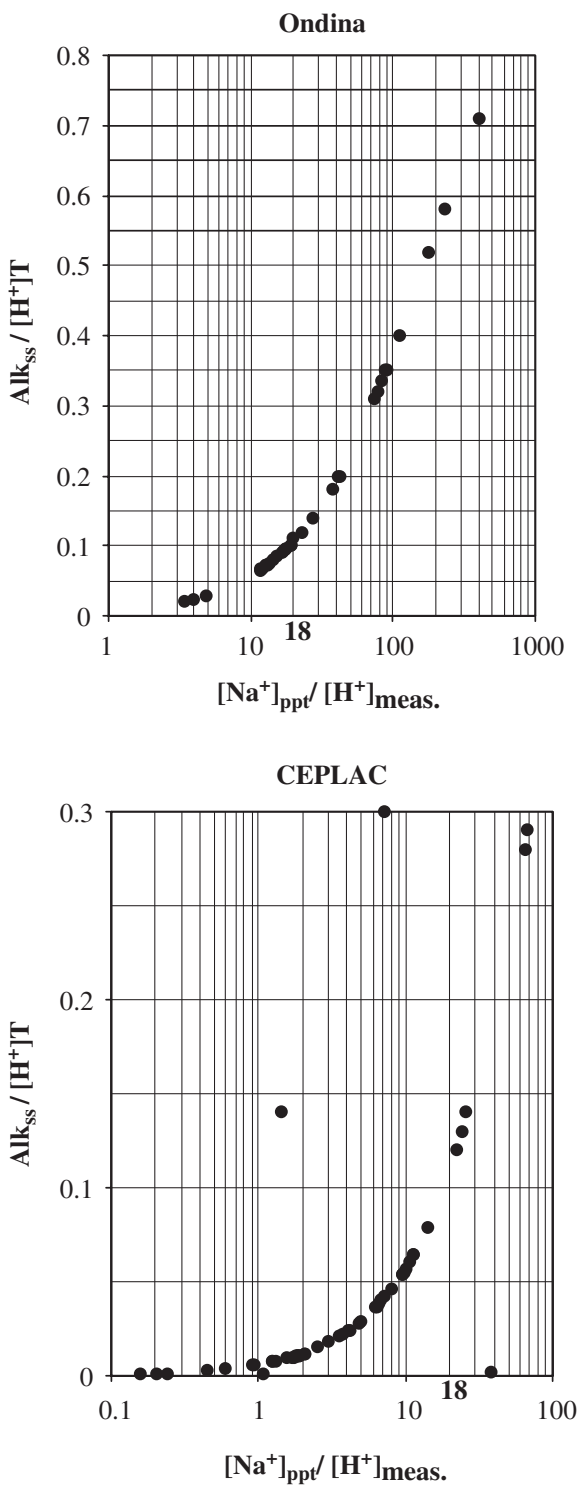

agent for precipitation acidity in the four Recôncavo stations. A fair number of rain samples had more than $10 \%$ of their acidity neutralized in this way, mainly at the Ondina station, $500 \mathrm{~m}$ from the coast. More than $10 \%$ of the acidity of $53 \%$ of the rain samples from Ondina was neutralized. Also $30 \%$ of the samples from CIBEB, $27 \%$ in Pedra do Cavalo and $12.5 \%$ in CEPLAC station were neutralized. Apart from the last station, the other sites showed some extreme cases of more than $50 \%$ of rain acidity neutralized by seaspray. Acidity was calculated as described above, considering alkalinity of seaspray $>50 \%$ of total acidity of rain $\left([\mathrm{Alk}]_{\mathrm{ss}} /\left[\mathrm{H}^{+}\right]_{\mathbf{T}}>50 \%\right)$. It can be concluded that $\left[\mathrm{Na}^{+}\right]_{\mathrm{ppt}} /\left[\mathrm{H}^{+}\right]_{\text {meas. }}>166$.

\subsection{Direct method to quantify the percentage of neutralized} rain acidity by seaspray, in the studied area

In order to provide a simple and practical way to estimate the percentage of rain neutralization for the
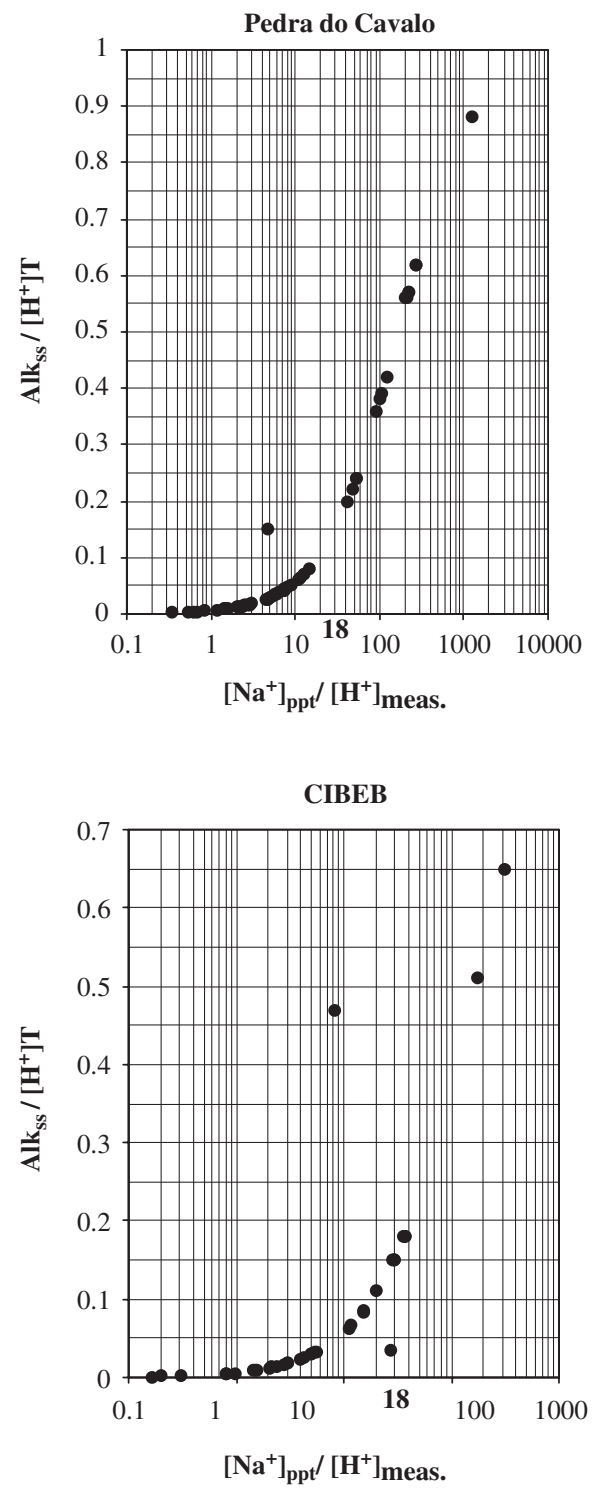

Fig. 5. Importance of the seaspray as an acidity neutralization agent on the precipitation of Recôncavo, Bahia, Brazil. 


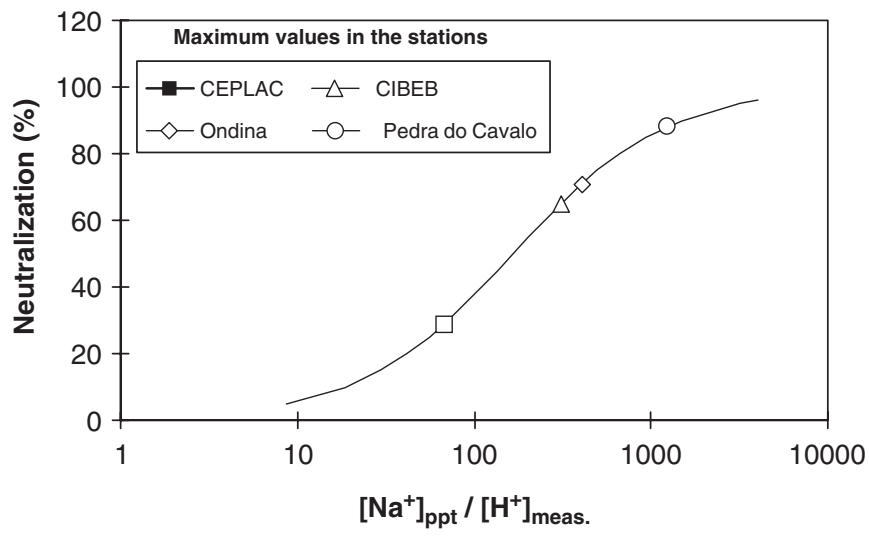

Fig. 6. Neutralization percentages of the rain samples acidity by seaspray, Recôncavo, Bahia, Brazil.

Recôncavo for further studies, a plot of the percentage of neutralization against the $\left[\mathrm{Na}^{+}\right]_{\mathrm{ppt}} /\left[\mathrm{H}^{+}\right]_{\text {meas. }}$, using all data from the four sites of the Recôncavo was built. As conditions of all NE coastlines of Brazil are similar, this plot can be easily used for this purpose and similar plots can be built for other regions with marine influence in the absence of other sodium sources (Fig. 6).

\section{Conclusions}

For all rain samples from the four stations of Recôncavo, there was a measurable degree of neutralization by seaspray. The highest percentage of neutralization, as expected, was found at $500 \mathrm{~m}$ downwind from the Atlantic coast. On average, $18 \%$ (range: $2.0-71 \%$ ) of rain acidity at this site was neutralized by seaspray. For more than a half of the collected samples, the neutralization exceeded $10 \%$. The rural station (CEPLAC), at $55 \mathrm{~km}$ downwind from the Atlantic coast and $35 \mathrm{~km}$ downwind from the industrial area, showed the lowest seaspray influence, with an average neutralization of $5 \%$ (range: $<1-30 \%$ ) of acidity. This low neutralization was attributed to the fluctuation of seaspray loads due to wind patterns. The average neutralization by seaspray at CIBEB station, $22 \mathrm{~km}$ downwind from the Atlantic coast and $2 \mathrm{~km}$ downwind of the industrial region was $8.5 \%$ (range: $<1-65 \%$ ). In Pedra do Cavalo, at $120 \mathrm{~km}$ downwind from the Atlantic coast and $105 \mathrm{~km}$ downwind from the industrial area, the average neutralization by seaspray was $14 \%$ (range: $<1-88 \%$ ). Therefore, the incorporation of seaspray into rain at Recôncavo, Bahia, neutralized on average $5-18 \%$ of precipitation acidity.

\section{Acknowledgments}

We are indebted to Deutsche Akademische Austauschdienst (DAAD) and the Stiftung Volkswagenwerk for the donation of several equipments used in this study and to $\mathrm{CNPq}$ for the research scholarship granted to the last author.

\section{References}

Ahmed, A.F.M., Singh, R.P., Elmubarak, A.H., 1990. Chemistry of atmospheric precipitation at the western Arabian Gulf Coast. Atmospheric Environment 24A, 2927-2934.

Al Momani, I.F., 2003. Trace elements in atmospheric precipitation at Northern Jordan measured by ICP-MS: acidity and possible sources. Atmospheric Environment 37, 4507-4515.

Al-Momani, I.F., Ataman, O.Y., Anwari, M.A., Tuncel, S., Köse, C., Tuncel, G., 1995. Chemical composition of precipitation near an industrial area at Izmir, Turkey. Atmospheric Environment 29, 1131-1143.

Avila, A., Peñuelas, J., 1999. Increasing frequency of Saharan rains over northeastern Spain and its ecological consequences. Science of the Total Environment 228, 153-156.

Bruynseels, F., Tavares, T.M., Van Grieken, R., 1985. Characterization of individual particle types in coast air by laser microprobe analysis. International Environmental and Analytical Chemistry 23, 1-14.

Campos, V.P., 1995. Especiação Inorgânica de Enxofre, Nitrogênio e Cloro na Precipitação Seca e Úmida no Recôncavo Baiano. Ph.D. Thesis, Instituto de Química-UFBA, Salvador-Bahia, Brazil (in Portuguese).

Campos, V.P., Costa, A.C.A., Tavares, T.M., 1998. Comparação de dois tipos de amostragem de chuva: Deposição total e deposição apenas úmida em área costeira tropical. Quimica Nova 21, 418-423 (in Portuguese).

Chameides, W.L., Stelson, A.W., 1992. Berichte der Bunsen-Gesellschaft. Physical Chemistry Chemical Physics 96 (3), 461.

Charlson, R.J., Rodhe, H., 1982. Factors controlling the acidity of natural rainwater. Nature 295, 683-685.

Ezcurra, A., Casado, H., Lacaux, J.P., Garcia, C., 1988. Relationships between meteorological situations and acid rain in Spanish Basque Country. Atmospheric Environment 22 (12), 2779-2786.

Flues, M., Hama, P., Lemes, M.J.L., Dantas, E.S.K., Fornaro, A., 2002. Evaluation of the rainwater acidity of rural region due to a coal-fired power plant in Brazil. Atmospheric Environment 36, 2397-2404.

Galloway, J.N., Likens, G.E., Keene, W.C., Miller, J.M., 1982. The composition of precipitation in remote areas of the world. Journal of Geophysical Research 87 (11), 8771-8786.

Galloway, J.N., Knap, A.H., Church, T.J., 1983. The composition of western Atlantic precipitation using shipboard collectors. Journal of Geophysical Research 88 (C15), 10,859-10,864.

Gillett, R.W., Ayers, G.P., Noller, B.N., 1990. Rainwater acidity at Jabiru, Australia, in the wet season of $1983 / 84$. Science of the Total Environment 92, 129-144.

Glavas, S., Moschonas, N., 2002. Origin of observed acidic-alkaline rains in a wet-only precipitation study in a Mediterranean coastal site, Patras, Greece. Atmospheric Environment 36, 3089-3099.

Granat, L., 1972. On the relation between $\mathrm{pH}$ and the chemical composition in atmospheric precipitation. Tellus 24, 550-560.

Herut, B., Starinsky, A., Katz, A., Rosenfeld, D., 2000. Relationship between the acidity and chemical composition of rainwater and climatological conditions along a transition zone between large deserts and Mediterranean climate, Israel. Atmospheric Environment 34, 1281-1292.

Jickells, T., Knap, A., Church, T., Galloway, J., Miller, J., 1982. Acid rain on Bermuda. Nature 297, 55-57.

Kramer, J.R., 1978. Acid precipitation. In: Nriagu, J.O. (Ed.), Sulfur in the Environment. Wiley, New York, p. 325.

Kulshrestha, U.C., Sarkar, A.K., Srivastava, S.S., Parashar, D.C., 1996. Investigation into atmospheric deposition through precipitation studies at New Delhi (India). Atmospheric Environment 30, 4149-4154.

Kulshrestha, U.C., Kulshrestha, M.J., Sekar, R., Sastry, G.S.R., Vairamani, S.M., 2003. Chemical characteristics of rainwater at an urban site of south-central India. Atmospheric Environment 37, 3019-3026. 
Lee, B.K., Hong, S.H., Lee, D.S., 2000. Chemical composition of precipitation and wet deposition of major ions on the Korean peninsula. Atmospheric Environment 34, 563-575.

Loye-Pilot, M.D., Martin, J.M., Morelli, J., 1986. Influence of Saharan dust on the rain acidity and atmospheric input to the Mediterranean. Nature 321, 427-428.

Munger, J.W., Eisenreich, S.J., 1983. Continental-scale variations in precipitation chemistry. Environmental Science and Technology 17, $32 \mathrm{~A}-42 \mathrm{~A}$.

Possanzini, M., Buttini, P., Di Palo, V., 1988. Characterization of a rural area in terms of dry and wet deposition. Science of the Total Environment 74, 111-120.

Sanusi, A., Wortham, H., Millet, M., Mirabel, P., 1996. Chemical composition of rainwater in eastern France. Atmospheric Environment 30, 59-71.

Satsangi, G.S., Lakhani, A., Khare, P., Singh, S.P., Kumari, K.M., Srivastava, S.S., 1998. Composition of rainwater at a semiarid rural site in India. Atmospheric Environment 32, 3783-3793.

Saxena, A., Kulshrestha, U.C., Kumar, N., Kumari, K.M., Srivastava, S.S., 1996. Characterization of precipitation at Agra. Atmospheric Environment 30, 3405-3412.
Sharma, M., McBean, E.A., 1995. Prediction of atmospheric sulphate deposition at sensitive receptors in northern India. Atmospheric Environment 29, 2157-2162.

Skirrow, G., 1975. The dissolved gases - carbon dioxide. In: Riley, J.P., Skirrow, G. (Eds.), Chemical Oceanography. Academic Press, London, pp. 25-192.

Tavares, T.M., Rocha, V.C., Nogueira, E.M., Van Grieken, R., Klockow, D., 1993. The influence of seaspray on the atmospheric chemistry of the Recôncavo of Bahia, Brazil. Revista International de Contaminación Ambiental (International Journal of Environmental Pollution) 9 (Suppl 2), 50-66.

Terada, H., Ueda, H., Wang, Z., 2002. Trend of acid rain and neutralization by yellow sand in East Asia - a numerical study. Atmospheric Environment 36, 503-509.

Tuncer, B., Bayar, B., Yesilyurt, C., Tuncel, G., 2001. Ionic composition of precipitation at the Central Anatolia, Turkey. Atmospheric Environment 35, 5989-6002.

Warneck, P., 1988. Chemistry of the Natural Atmosphere. Academic Press Inc., New York.

Zhou, G., Tazaki, K., 1996. Seasonal variation of gypsum in aerosol and its effect on the acidity of wet precipitation on Japan seaside of Japan. Atmospheric Environment 30, 3301-3308. 